\title{
The Effect of Fertilizer Type-Mucuna and NPK, on the proximate Values of Orange Flesh Sweet Potato.
}

\author{
Tolubanwo, S.E. ${ }^{*}$, Okereke, N.A.A. ${ }^{2}$, Madubuike, C. N. ${ }^{2}$, Nwandikom, G.I. ${ }^{2}$, Oti, N.N. ${ }^{2}$ \\ ${ }^{I}$ National Root Crops Research Institute (NRCRI), Umudike, Abia-Nigeria. \\ ${ }^{2}$ Federal University of Technology Owerri, (FUTO), Imo-Nigeria.
}

*Corresponding Author: Tolubanwo, S.E., National Root Crops Research Institute (NRCRI), Umudike, Abia-Nigeria.

\begin{abstract}
Sweet potato (Ipomoea batatas), even though is regarded as "poor man's food" or "famine crop" has contributed greatly to promote food security which also reduces poverty. It is also used to supplement as an alternative staple food for poor farmers as a result of its diverse range of positive attributes like high nutritional value, short duration and tolerance to difference production stresses. The orange flesh sweet potato is considered as an important member of the tropical tuber crops which has high possibility for being adopted as regular diet of consumer food chain to solve the problem of vitamin A malnutrition. This study evaluated the effect of fertilizer type - Mucuna as an alternative source of fertilizer and to compare its effect on proximate and mineral value comparable to NPK (Nitrogen- Phosphorus-Potassium) fertilizer. The source of Nitrogen was from Mucuna pod powder and NPK fertilizer which were used for orange flesh sweet potato production for 2years. Equal quantity of Mucuna and NPK and irrigation (0, 200,400 and $600 \mathrm{~kg} / \mathrm{ha}$ ) and irrigation once every three days were applied. The proximate composition of the flesh sweet potato was determined using standard assay techniques. The starch yield $70.51 \%$ of Mucuna pod fertilizer and $67.23 \%$ of NPK fertilizer, crude fiber $2.10 \%$ of Mucuna pod fertilizer and1.61\% of NPK fertilizer, carbohydrate $19.36 \%$ of Mucuna pod fertilizer and $20.46 \%$ of NPK fertilizer, reducing sugar $1.44 \%$ of Mucuna pod fertilizer and $1.72 \%$ of NPK fertilizer, crude protein $4.91 \%$ of Mucuna pod fertilizer and $4.34 \%$ of NPK fertilizer, crude lipids $1.16 \%$ of Mucuna pod fertilizer and $1.22 \%$ of NPK fertilizer. Ash content $1.86 \%$ of Mucuna pod fertilizer and $1.91 \%$ of NPK fertilizer for OFSP of $400 \mathrm{~kg} / \mathrm{h}$ a of every three days' irrigation. In starch yield, crude protein, crude lipids and Ash content of OFSP yield, Mucuna pod powder fertilizer was significantly higher $(p<0.05)$ than NPK fertilizer. The carbohydrate and reducing sugar content of OFSP of Mucuna pod powder fertilizer was significantly lower than NPK fertilizer.
\end{abstract}

The Calcium content of (76.03mg and 72.78mg), Sodium content (38.41mg and 36.03mg), Magnesium (19.38mg and 19.62mg), Phosphorous (34.24mg and 51.32mg), Potassium (151.05mg and 192.22mg), Iron (5.24mg and 5.81mg), Zinc 2.95mg and 2.60mg) and total Carotenoid (86.43mg and 85.10mg) of the OFSP yield, Mucuna pod powder fertilizer and NPK fertilizer are significantly difference.

The calcium, sodium, magnesium, zinc and carotenoid content in OFSP of Mucuna pod powder are significantly higher $(p<0.05)$ than NPK content in OFSP. While phosphorous, potassium and Iron content in OFSP of NPK are significantly higher ( $p<0.05)$ than Mucuna pod powder content in OFSP. From the analysis result it can be advising that Mucuna pod powder can be use in place of NPK since the nutritional value of both fertilizers yield is within the same range.

Keywords: Mucuna Pod Powder, NPK, Orange flesh sweet potato and Irrigation scheduling.

\section{INTRODUCTION}

Sweet potato is a co-staple in sub-Sahara Africa's densely populated, intensively cultivated midelevation farming areas. In many other countries it is an important secondary crop grown for an expanding fresh market. It provides vitamins, minerals, proteins and carbohydrates to human kind. It can also be used as animal feed, source of starch and for industrial purposes. According to Burri, (2011), "the orange-fleshed sweet potato (OFSP) has been found to be a cheap but crucially important remedy for nutritional deficiency due to the fact that the OFSP cultivars contain high quantities of provitamin A". Giller (2003) stated that "Leguminous plants are rated among the most bountiful and perfect gifts of nature. The adoption and use of diversified cropping practices has become widely 
accepted by producers. However, the profitability of an enterprise is dependent on the biophysical and economic factors". Legumes provide a large number of products, and at the same time they enhance soil fertility (Undie, et al., 2013). Imoro, et al., (2013) concluded that the result obtained from the research carried out on assessing soil amendments potential of Mucuna Pruriens and crotalaria juncea used as fallow crops showed "significant effect of Mucuna Pruriens and Crotalaria Juncea on the soil as it led to an increase in the chemical parameters studied in terms of the levels of nitrogen, phosphorous, potassium, organic carbon and soil $\mathrm{pH}$ after incorporating the organic materials into the soil". Most developing countries are faced with Vitamin A deficiency which result in children blindness as well as increase mortality in such countries. Mohammad et al., (2016) stated that "Malnutrition caused by the deficiency of vitamin A is known to be widespread among the rural people of developing countries, including Bangladesh. This deficiency causes children to succumb to common diseases and leads to the impairment of growth and development, vision impairment, poor immune functions and, in extreme cases, results in blindness and death

Somasundaram, et al., (2008) stated that "vitamin A malnutrition is a major public health concern of the developing countries and is responsible for millions of deaths annually among the young children. The nutritionists in several developing countries compelled the evidence of lack of adequate essential vitamins and minerals in the diet of many children and adults".

\subsection{The Effect of Nitrogen Management on Sweet Potato.}

Nitrogen is very important in sweet potato production. The Nitrogen can be gotten from chemical or organic fertilizer. According to Tara, (2016) "in sweet potato management and to have sustainable and profitable commercial sweet potato production, it requires proper management of nitrogen fertilizer. However, inadequate or excessive amounts of nitrogen fertilizer can be detrimental to sweet potato crop and can negatively affect yield potential. More so, excessive or improperly timed nitrogen fertilizer can result in added expenses, leaching and contamination of surface and ground water. It is therefore necessary that informed decisions which considers crop history and soil type are important factors to consider in determining the proper amount of nitrogen fertilizer that should be applied in a sweet-potato production field."

Anthofer, (1999) and Undie et al., (2013) stated that "inclusion of these legumes into the farming systems has been shown to contribute nutrients to the soil through nitrogen fixation and through recycling of residues which also contribute organic matter into the soil".

\section{Materials AND MethodS}

\subsection{Experimental Design and Treatments}

A $3 \times 7$ treatments design was laid out in a randomized complete block (RCDB) in split-split plot arrangement with three replications. Each replication was made up of twenty-one plots measuring 4.8 x $4 \mathrm{~m}$ (plot area $=19.2 \mathrm{~m}^{2}$ ). Each plot contains plant population of 64 stands. In the layout alley of $1 \mathrm{~m}$ and $2 \mathrm{~m}$ were left between the plots and replicates respectively to avoid treatment drift to adjacent plots.

One variety of sweet potato namely; orange fleshed sweet potato (OFSP) mother's delight, one irrigation method (Furrow), three irrigation scheduling, and seven fertilizer rates. In the treatment, three irrigation scheduling [once every two days (E2D), (once every three days (E3D and once every four days (E4D)], and the sub-plots are seven fertilizer rates $(0,200 \mathrm{~N}, 200 \mathrm{M}, 400 \mathrm{~N}, 400 \mathrm{M}, 600 \mathrm{~N}$ and $600 \mathrm{M} \mathrm{kg} \mathrm{N} / \mathrm{ha})$. The two sources of fertilizer [NPK (N): 15:15:15 and Mucuna pod granular (M)] were used and with a control (no fertilizer). A known amount of irrigation water was applied throughout the study. The Specific weights $(\mathrm{kg} / \mathrm{ha})$ of Nitrogen $(\mathrm{N})$ of both fertilizers was calculated before application. The matured Mucuna pods were harvested and the pods without the beans dried to aid grinding with hammer mill and later analysed following standard procedures (Udo et al, 2009). The orange-fleshed sweet-potato (OFSP) vines were obtained from the National Root Crops Research Institute (NRCRI), Umudike. The data collected were subjected to analysis of variance using R programming language version 3.4.4 statistical package.

\subsection{Data Collection and Analysis}

All analysis was carried out in triplicates. The methods described below were used for specific analysis

\subsubsection{Proximate Analysis of Orange Flesh Sweet Potato.}

Proximate analysis according AOAC (2000) it's the determination of a group of components closely related together, e.g. total protein, fat, etc." It conventionally includes determinations of the amount of water, protein, fat (ether extract), ash and fibre, with nitrogen-free extract 


\subsubsection{The Moisture Determination}

The moisture content was determined according to AOAC (2000) using the official method 925.09 by oven drying. Also, it determined

\subsubsection{The Determination of Protein}

Protein content was determined according to AOAC (2000) using the official method 979.09.

\subsubsection{The Determination of Ash}

Total ash content was determined according to AOAC (2000) using the official method 923.03.

\subsubsection{The Determination of Crude Fibre}

Crude fiber content was determined according to AOAC (2000) using official method 962.09.

\subsubsection{Determination of Fat}

The crude fat content was determined according to AOAC (2000) using official method 4.5.01.

\subsubsection{Determination of Carbohydrate}

Total carbohydrate content was calculated by difference using the formula as follows: Carbohydrate $(\%)=100-(\%$ crude protein $+\%$ crude fiber $+\%$ total ash $+\%$ crude fat $)$

\subsection{The Determination of Mineral}

The mineral content of the sample was actually determined by following the method AOAC (2000).

\subsubsection{The Determination of Potassium by Flame Photometry.}

In this work, Jaway digital flame photometer equipment was used in the determination of potassium. It was switched on and allowed to stand for 15 minutes so as to calibrate to

\subsubsection{The Determination of Phosphorus.}

Phosphorus was determined according to AOAC (2000) using an Atomic Absorption Spectrophotometer (Varian SAA-20 Plus). Also, according to Nwosu, et al., (2014).

\subsubsection{Determination of Calcium and Magnesium by Complex metric Titration}

Calcium and Magnesium were determined according to AOAC (2000) using an Atomic Absorption Spectrophotometer (Varian SAA-20 Plus). Also, according to Nwosu, et al. (2014).

\subsubsection{Determination of Zinc, Copper, and Iron}

Zinc, Copper, and Iron were determined according to the standard method of AOAC (2000) using UV-VIS spectrometer.

\section{RESULTS AND DisCUSSIONS}

The OFSP (mother delight) planted with NPK and grinded Mucuna pod as inorganic and organic fertilizer in NRCRI was harvested for consumption.

Table1. Proximate Composition of OFSP

\begin{tabular}{|c|c|c|c|c|c|c|c|c|}
\hline SAMPLE & CL & ASH & CHO & RS & ST & MC & CP & CF \\
\hline $0 / 3$ & $0.95 \mathrm{e}$ & $1.72 \mathrm{e}$ & $21.71 \mathrm{a}$ & $1.61 \mathrm{c}$ & $23.07 \mathrm{~g}$ & $69.06 \mathrm{f}$ & $3.58 \mathrm{~g}$ & $1.94 \mathrm{c}$ \\
\hline $200 \mathrm{M} / 3$ & $1.18 \mathrm{c}$ & $1.85 \mathrm{c}$ & $20.65 \mathrm{c}$ & $1.72 \mathrm{a}$ & $27.61 \mathrm{~d}$ & $70.18 \mathrm{~d}$ & $4.11 \mathrm{e}$ & $2.05 \mathrm{~b}$ \\
\hline $200 \mathrm{~N} / 3$ & $1.15 \mathrm{~d}$ & $1.78 \mathrm{~d}$ & $21.41 \mathrm{~b}$ & $1.66 \mathrm{~b}$ & $27.25 \mathrm{e}$ & $70.06 \mathrm{e}$ & $3.84 \mathrm{f}$ & $1.77 \mathrm{~d}$ \\
\hline $400 \mathrm{M} / 3$ & $1.22 \mathrm{a}$ & $1.91 \mathrm{~b}$ & $19.36 \mathrm{e}$ & $1.44 \mathrm{~d}$ & $29.52 \mathrm{c}$ & $70.15 \mathrm{~b}$ & $4.91 \mathrm{~b}$ & $2.10 \mathrm{a}$ \\
\hline $400 \mathrm{~N} / 3$ & $1.16 \mathrm{~d}$ & $1.86 \mathrm{c}$ & $20.46 \mathrm{~d}$ & $1.71 \mathrm{a}$ & $24.41 \mathrm{f}$ & $67.23 \mathrm{~g}$ & $4.34 \mathrm{~d}$ & $1.61 \mathrm{f}$ \\
\hline $600 \mathrm{M} / 3$ & $1.21 \mathrm{~d}$ & $1.98 \mathrm{a}$ & $18.29 \mathrm{f}$ & $1.71 \mathrm{a}$ & $32.72 \mathrm{a}$ & $70.93 \mathrm{a}$ & $5.51 \mathrm{a}$ & $2.10 \mathrm{a}$ \\
\hline $600 \mathrm{~N} / 3$ & $1.23 \mathrm{a}$ & $1.91 \mathrm{~b}$ & $20.09 \mathrm{e}$ & $1.65 \mathrm{~b}$ & $31.66 \mathrm{~b}$ & $70.43 \mathrm{c}$ & $4.69 \mathrm{c}$ & $1.67 \mathrm{e}$ \\
\hline LSD & $\mathbf{0 . 0 2 3 1}$ & $\mathbf{0 . 0 3 1 1}$ & $\mathbf{0 . 0 3 1 1}$ & $\mathbf{0 . 1 7 1 8}$ & $\mathbf{0 . 0 7 2 6}$ & $\mathbf{0 . 0 6 5 1}$ & $\mathbf{0 . 0 4 0 7}$ & $\mathbf{0 . 0 3 1 4}$ \\
\hline
\end{tabular}

Values are means of tripartite observations. Means with similar alphabets are not significantly different $(p>0.05)$ at $5 \%$ level of significance. LSD is the Least Significant Difference.

Sample 0/3 is no fertilizer at once every three-day irrigation.

Sample $200 \mathrm{M} / 3$ is $200 \mathrm{~kg} / \mathrm{ha}$ of Mucuna equivalent at once every three- day irrigation. 
Sample $200 \mathrm{~N} / 3$ is $200 \mathrm{~kg} / \mathrm{ha}$ of NPK at once every three- day irrigation.

Sample $400 \mathrm{M} / 3$ is $400 \mathrm{~kg} / \mathrm{ha}$ of Mucuna equivalent at once every three- day irrigation.

Sample $400 \mathrm{~N} / 3$ is $400 \mathrm{~kg} / \mathrm{ha}$ of NPK at once every three- day irrigation.

Sample $600 \mathrm{M} / 3$ is $600 \mathrm{~kg} / \mathrm{ha}$ of Mucuna equivalent at once every three- day irrigation.

Sample $600 \mathrm{~N} / 3$ is $600 \mathrm{~kg} / \mathrm{ha}$ of NPK at once every three- day irrigation.

$\mathrm{CL}=$ Crude lipids. $\mathrm{ASH}=$ Ash content $\mathrm{CHO}=$ Carbohydrate. $\mathrm{RS}=$ Reducing sugar.

$\mathrm{ST}=$ Starch Yields. $\mathrm{MC}=$ Moisture Content. $\mathrm{CP}=$ Crude Protein. $\mathrm{CF}=$ Crude Fiber.

From table 1, the Crude Lipids content of the OFSP for the two fertilizer sources varied using 400M/3 and $400 \mathrm{~N} / 3$ as case study. The values ranged from 1.16 to $1.22 \%$. The CL content of Mucuna pod fertilizer $(1.22 \%)$ is significantly $(\mathrm{P}<0.05)$ higher than NPK fertilizer $(1.16 \%)$. The crude lipids values for the different fertilizer ranged from 1.16-1.22\%. Although these values were low, there are comparable to the values of 1.10-2.0\% reported by Ukom et al., (2009) data. The ash content of the OFSP for the two fertilizer sources ranged from 1.86 to $1.91 \%$. The ash content of Mucuna pod fertilizer $(1.91 \%)$ is significantly $(\mathrm{P}<0.05)$ higher than NPK fertilizer $(1.86 \%)$. The result here agreed with Mohammad et al., (2016) which reported that ash content of the OFSP ranged from $1.26 \%$ to $1.35 \%$. The CHO content of the OFSP for the two fertilizer sources ranged from 19.36 to $20.46 \%$. The CHO content of NPK fertilizer $(20.46 \%)$ is significantly $(\mathrm{P}<0.05)$ higher than the Mucuna pod fertilizer $(19.36 \%)$. The result obtained in this study agreed with Mohammad et al., (2016) that carbohydrate content was between $21 \%$ and $25 \%$ in fresh samples of OFSP. The RS contents of the OFSP for the two fertilizer sources ranged from 1.44 to $1.71 \%$. The RS content of NPK fertilizer $(1.71 \%)$ is significantly $(\mathrm{P}<0.05)$ higher than the Mucuna pod fertilizer $(1.44 \%)$. The values are comparable to data reported by Mitra et al., (2012).The starch contents of the OFSP for the two fertilizer sources ranged from for the two fertilizer sources ranged from 70.51 to $67.23 \%$. This showed that the starch content of Mucuna pod fertilizer $(70.51 \%)$ is significantly $(\mathrm{P}<0.05)$ higher than NPK fertilizer (67.23\%). The result here agrees with Ukom et al., (2009) data. Mohammad et al., (2016) reported that fresh sweet potato had a moisture content of 70.95 to $72.96 \%$. The variations in the moisture content can be due to the season of planting and cultivation practices. The crude protein content of the OFSP for the two fertilizer sources ranged from 4.91 to $4.34 \%$. This showed that the crude protein content of Mucuna pod fertilizer $(4.91 \%)$ is significantly $(\mathrm{P}<0.05)$ higher than NPK fertilizer $(4.34 \%)$. This protein values are comparable to the average protein value of $1.91 \%$ to $5.83 \%$ reported by Mohammad et al. (2016). In this table also, the crude fiber content of the OFSP for the two fertilizer sources ranged from 1.61 to $2.10 \%$. The CF content of Mucuna pod fertilizer $(2,10 \%)$ is significantly $(\mathrm{P}<0.05)$ higher than NPK fertilizer $(1.61 \%)$. The values comparable to data reported by Mohammad et al., (2016) and Ukom et al., (2009). The increase in Mucuna pod fertilizer also agrees with the report of Igbokwe et al., (2005) "that non-synthetic input cropping system enhanced crude fiber more than the conventional (chemical intensive) cropping system".

Table2. Mineral composition of OFSP

\begin{tabular}{|c|c|c|c|c|c|c|c|c|}
\hline $\begin{array}{c}\text { Fertilizer } \\
\text { rate/Irri. freq }\end{array}$ & K & Fe & Zn & CAR & Ca & Na & Mg & P \\
\hline $0 / 3$ & $186.17 \mathrm{~d}$ & $5.14 \mathrm{e}$ & $3.85 \mathrm{a}$ & $82.64 \mathrm{e}$ & $73.68 \mathrm{~d}$ & $36.45 \mathrm{~d}$ & $22.42 \mathrm{a}$ & $42.11 \mathrm{~d}$ \\
\hline $200 \mathrm{M} / 3$ & $150.35 \mathrm{~g}$ & $4.91 \mathrm{f}$ & $2.9 \mathrm{~d}$ & $82.63 \mathrm{e}$ & $74.27 \mathrm{c}$ & $35.13 \mathrm{f}$ & $16.86 \mathrm{f}$ & $33.74 \mathrm{~g}$ \\
\hline $200 \mathrm{~N} / 3$ & $189.1 \mathrm{c}$ & $5.62 \mathrm{~b}$ & $2.53 \mathrm{~g}$ & $82.04 \mathrm{f}$ & $70.14 \mathrm{~g}$ & $33.22 \mathrm{~g}$ & $16.03 \mathrm{~g}$ & $49.78 \mathrm{c}$ \\
\hline $400 \mathrm{M} / 3$ & $151.05 \mathrm{f}$ & $5.24 \mathrm{~d}$ & $2.95 \mathrm{c}$ & $86.43 \mathrm{c}$ & $76.03 \mathrm{~b}$ & $38.41 \mathrm{c}$ & $19.62 \mathrm{~d}$ & $34.24 \mathrm{f}$ \\
\hline $400 \mathrm{~N} / 3$ & $192.22 \mathrm{~b}$ & $5.81 \mathrm{a}$ & $2.60 \mathrm{f}$ & $85.10 \mathrm{~d}$ & $71.63 \mathrm{f}$ & $36.03 \mathrm{e}$ & $19.38 \mathrm{e}$ & $51.32 \mathrm{~b}$ \\
\hline $600 \mathrm{M} / 3$ & $152.33 \mathrm{e}$ & $5.50 \mathrm{c}$ & $2.99 \mathrm{~b}$ & $92.15 \mathrm{a}$ & $77.31 \mathrm{a}$ & $40.33 \mathrm{a}$ & $20.15 \mathrm{~b}$ & $35.11 \mathrm{e}$ \\
\hline $600 \mathrm{~N} / 3$ & $193.26 \mathrm{a}$ & $5.86 \mathrm{a}$ & $2.82 \mathrm{e}$ & $90.40 \mathrm{~b}$ & $72.49 \mathrm{e}$ & $39.16 \mathrm{~b}$ & $20.04 \mathrm{c}$ & $53.15 \mathrm{a}$ \\
\hline LSD & $\mathbf{0 . 0 5 1}$ & $\mathbf{0 . 0 5 9}$ & $\mathbf{0 . 0 3 3}$ & $\mathbf{0 . 1 2 2}$ & $\mathbf{0 . 0 3 1}$ & $\mathbf{0 . 0 3 4}$ & $\mathbf{0 . 0 3 5}$ & $\mathbf{0 . 0 3 9}$ \\
\hline
\end{tabular}

Values are means of tripartite observations. Means with similar alphabets are not significantly different $(p>0.05)$ at $5 \%$ level of significance. LSD is the Least Significant Difference.

$\mathrm{K}=$ Potassium $. \mathrm{Fe}=$ Iron $. \mathrm{Zn}=$ Zinc $. \mathrm{CAR}=$ Carotenoids

$\mathrm{Ca}=$ Calcium $. \mathrm{Na}=$ Sodium $. \mathrm{Mg}=$ Magnesium $. \mathrm{P}=$ Phosphorus

From table 2, the discussion will be based on using $400 \mathrm{M} / 3$ and $400 \mathrm{~N} / 3$ as case study. The Potassium contents of the OFSP for the two fertilizer sources ranged from 151.05 to $192.22 \mathrm{mg}$. The K content of 
NPK fertilizer (192.22mg) is Mucuna pod fertilizer (151.05mg). The Iron contents of the OFSP for the fertilizer sources ranged from 5.24 to $5.81 \mathrm{mg}$. The Fe content of Mucuna pod fertilizer $(5.24 \mathrm{mg})$ is significantly lower than the NPK fertilizer $(5.81 \mathrm{mg})$. The Zinc contents of the OFSP for the two fertilizer sources ranged from 2.60 to $2.95 \mathrm{mg}$. The zinc content of Mucuna pod fertilizer $(2.95 \mathrm{mg})$ is significantly $(\mathrm{P}<0,05)$ higher than the NPK fertilizer $(2.60 \mathrm{mg})$. The CAR contents of the OFSP for the two fertilizer sources ranged from 85.10 to $86.43 \mathrm{mg}$. The CAR content of Mucuna pod fertilizer $(86.43 \mathrm{mg})$ is significantly higher than the NPK fertilizer $(85.10 \mathrm{mg})$. From table 2, increase in the application of nitrogen fertilizer from $0-600 \mathrm{kgN} / \mathrm{ha}$ increased $\beta$-carotene yield with the highest numerical value of $90.40 \mathrm{mg}$ for OFSP at $600 \mathrm{~N} / 3,92.15 \mathrm{mg}$ at $600 \mathrm{M} / 3$ for OFSP. This may indicate that nitrogen stimulate carotenoid biosynthesis, thus agreeing with the report of Ukom et al., (2009).

From the table also, Ca content of the OFSP for the two fertilizer sources ranged from 76.03 to $71.63 \mathrm{mg}$. The Ca content of Mucuna pod fertilizer $(76.03 \mathrm{mg})$ is significantly $(\mathrm{P}<0.05)$ higher than NPK fertilizer $(71.63 \mathrm{mg})$. The Na contents of the OFSP for the two fertilizer sources ranged from 36.03 to $38.41 \mathrm{mg}$. The Na content of Mucuna pod fertilizer $(38.41 \mathrm{mg})$ is significantly $(\mathrm{P}<0.05)$ higher than NPK fertilizer $(36.03 \mathrm{mg}$ ). Mg contents of the OFSP for the two fertilizer sources ranged from 19.38 to $19.62 \mathrm{mg}$. This showed that $\mathrm{Mg}$ content of Mucuna pod fertilizer (19.62mg) is significantly $(\mathrm{P}<0.05)$ higher than NPK fertilizer $(19.38 \mathrm{mg})$. Also, the $\mathrm{P}$ contents of the OFSP of the two fertilizer sources ranged from 34.24 to $51.32 \mathrm{mg}$. This showed that the Mucuna pod fertilizer $(34.24 \mathrm{mg})$ is significantly $(\mathrm{P}<0,05)$ lower than NPK fertilizer $(51.32 \mathrm{mg})$.

\section{CONCLuSion}

In this study, the results obtained shows that Mucuna pod powder fertilizer and NPK fertilizer are good sources of fertilizer for orange flesh sweet potato production with the content of B-carotene and protein in Mucuna pod powder fertilizer. Nitrogen fertilizer application improved the B-carotene and protein contents of fertilizer rate/ irrigation frequency at $200-600 \mathrm{~kg} / \mathrm{ha} / 3$, while the zero fertilizer control has the highest zinc and magnesium in table 2. From the tables 1 and 2, Mucuna pod fertilizer performed better in most of the proximate and mineral component. As a result of this, Mucuna pod powder fertilizer can be used in place of NPK fertilizer. The use of Mucuna pod fertilizer, our soil will be enriched with our natural manure without soil degradation.

\section{REFERENCES}

[1] Anthofer, J. (1999). Experimentation and experiences of famers with Mucuna cover crop system in Ghana. Proceedings of the $2^{\text {nd }}$ CIEPCA workshop, October 1999, Cotonou, ASHS Press, Arlington, VA, Appl. Soil Ecol. 27: 197-210.

[2] AOAC (2000). Association of Official Analytical Chemists. Official Methods of Analysis, 17th edition. Washington, DC.

[3] Burri, B.J. 2011. Evaluating sweet potato as an intervention food to prevent vitamin A deficiency. Compr. Rev. Food Sci. Food Safety 10:118-130.

[4] Giller, K. (2003). Kick Starting Legumes, Plant Systems Research, Wageningen University \& Research Centre. P.O. Box 430, 6700 AK, Wageningen. The Netherlands, Leisa Magazine.

[5] Imoro, A. Z., Gakpo, S. P., and Khan, A. T., (2013). Assessing soil amendment potentials of Mucuna pruriens and Crotalaria juncea when used as fallow crops, Journal of Soil Science and Environmental Management, Vol. 4(2), pp. 28-34, May 2013.

[6] Igbokwe, E.I., L.C. Haum, F.O. Chukwuma and J. Huam, 2005. Sweet potato yield and quality as influenced by cropping systems. J. Vegetable Sci., 11: 35-46.

[7] Mohammad Khairul Alam, Ziaul Hasan Rana and Sheikh Nazrul Islam (2016). Comparison of the Proximate Composition, Total Carotenoids and Total Polyphenol Content of Nine Orange-Fleshed Sweet Potato Varieties Grown in Bangladesh. www.mdpi.com/journal/foods. 5, 64; Pp 1-10

[8] Nwosu, O. I. C., Nnam, N. N., Ibeziako, N. \& Maduforo, A.N. (2014) Development and Nutritional Evaluation of Infant Complementary Food from Maize (Zea Mays), Soybean (Glycine Max) and Moringa Oleifera Leaves. International Journal of Nutrition and Food Sciences. Vol. 3, No. 4, 2014, pp. 290-299. doi: 10.11648/j.ijnfs.20140304.19.

[9] Obiakor-Okeke, P. N.*, Obioha, B. C., Onyeneke, E. N. (2014): Nutrient and sensory evaluation of traditional soups consumed in Igbere community in Bende local government area, Abia State, Nigeria, International Journal of Nutrition and Food Sciences, 2014; 3(5): 370-379 Published online August 20, 2014 (http://www.sciencepublishinggroup.com/j/ijnfs) doi: 10.11648/j.ijnfs.20140305.12,ISSN: 23272694 (Print); ISSN: 2327-2716 (Online). 
[10] Somasundaram, K. and Santhosh Mithra, V.S. (2008). Madhuram: A Simulation Model for Sweet Potato Growth, World Journal of Agricultural Sciences 4 (2): 241-254, 2008, ISSN 1817-3047, (C) IDOSI Publications, 2008.

[11] Tara P. S. and Arthur Q. V. (2016). Nitrogen Management in Louisiana; Louisiana State University Agricultural Center; http://www.lsuagcenter.com/portals/communications/publications/publications_ catalog/crops_ livestock/commercial\%20fruits\%20and\%20vegetables/nitrogen-management-in-louisianasweet-potatoes.

[12] Udo, E J., T.O. Ibia, J.O. Ogunwale, A.O. Ano\& I. Esu (2009). Manual of Soil, Plant and Water Analysis. Sibon Books Ltd. Lagos.

[13] Ukom, A.N, Ojimelukwe, P.C. and Okpara, D.A., (2009). Nutrient Composition of Selected Sweet Potato [Ipomea batatas (L) Lam] Varieties as Influenced by Different Levels of Nitrogen Fertilizer Application. Pakistan Journal of Nutrition, 8: 1791- 1795.

[14] Undie, U.L.; Kekong, M.A. \& Ojikpong, T. (2013). Moringa ((Moringa oleifera Lam.) leaves effect on soil pH and garden egg (Solanum aethiopicum L.) yield in two Nigeria agro- ecologies. European Journal of Agriculture and Forestry Research 1: 17-25.

Citation: Tolubanwo, S.E., et.al, "The Effect of Fertilizer Type-Mucuna and NPK, on the proximate Values of Orange Flesh Sweet Potato.” International Journal of Research Studies in Agricultural Sciences (IJRSAS), 2019; 5(11), pp. 52-57, http://dx.doi.org/10.20431/2454-6224.0511007

Copyright: (C) 2019 Authors. This is an open-access article distributed under the terms of the Creative Commons Attribution License, which permits unrestricted use, distribution, and reproduction in any medium, provided the original author and source are credited. 